\title{
Defining Suitable Parking Controls to Minimize Negative Impacts of Road Traffic: A Case Study in Padang City
}

\author{
Gusri Yaldi $^{\#}$, Imelda M. Nur ${ }^{*}$, Apwiddhal ${ }^{\#}$, Momon ${ }^{1}$ \\ \# Civil Engineering Department, Politeknik Negeri Padang, Padang, 25168, Indonesia \\ E-mail: gusri.yaldi@yahoo.com,widdpoli@yahoo.com \\ * Business Administration Department, Politeknik Negeri Padang, Padang, 25168, Indonesia \\ E-mail: imeldamnur@yahoo.com \\ ${ }^{1}$ Bappeda Sumatera Barat, Padang, 25168, Indonesia \\ E-mail: abufadhil.2005@gmail.com
}

\begin{abstract}
Although car usage is admitted to improve the efficiency of travel and productivity, it is also blamed for the widespread problems in urban areas. It demands an increasing space for road as well as for parking, especially within Central Business District (CBD). Due to budget constraints and also to minimize the negative impacts of road traffic such as fossil fuel crisis and increasing number of road traffic accidents- parking control becomes essential. This study attempts to define the parking behaviour of motorists such as parking cost and duration, parking location distance, as well as pricing systems with a case study in Padang City, Indonesia. The findings from this study are expected could help the government in developing suitable parking controls inside the CBD and hence could contribute to minimizing the negative impacts of road transports. In addition, the government may also encourage the usage of public transports instead of private cars by using the recommended parking controls generated from this research. This is considerably important, especially for a country where a great amount of national petrol consumption are imported from overseas and mostly spent by private car and logistic transport.
\end{abstract}

Keywords - Parking Control; Road Traffic Impacts; On-Street Parking; Off-Street Parking; WTP; ATP

\section{INTRODUCTION}

The negative impacts of road traffic such as energy crisis, congestion, air pollution and road accident in Indonesia is now considered at an alarming level. The consumption of un-renewable energy source such as petroleum is the highest compared to other sources of energy while its deposit was predicted lasting for only about 18 years from 2006 [1]. About one third of national petrol consumption was imported and subsidized [2]. Meanwhile, Morichi [3] suggested the cruise speed on particular road sections in Indonesia is not more than $20 \mathrm{Km} /$ hour representing severe congestion level due to considerable unbalance growth rate between road length and automobile- about under $3 \%$ and above $10 \%$ respectively $[4,5]$. These figures and trends must be controlled so that further negative impacts of road traffic could be minimized due to its outcomes towards a country economic. The potential financial losses due to congestion and road accident are estimated up to three per cent of GDP and for developing countries like Indonesia the loss could be double as reported by Gwilliam [6] in Ma et al. [7]. Road traffic negative impacts could be minimized by increasing transport supply facilities as well as controlling its demand [8] such as managing parking supply and increasing public transport shares. A previous research by Luathep et al. [9] suggested that public transport share could be increased by introducing paid and limited parking facilities. It also demonstrated the $\mathrm{CO} 2$ produced by road traffic could be reduced up to $45.82 \%$. Yet, scientific based parking controls based on local conditions should be developed and hence it becomes applicable.

As an integral part of the public transport and road network, the parking facilities affect the commuter decision in choosing transport modes to use and hence contribute to the public transport patronage and congestion level. Parking control policy could be used to optimize the road transport, minimize congestion level and increase public transport share. Tsuboi [10] suggested the parking control could be 
used as an effective policy and hence understanding the traveller parking behaviour becomes essential. It includes on-street and off-street parking in the CBD. A study by Wijayaratna [11] demonstrated that on-street parking could reduce the road capacity to serve traffic up to $17 \%$ while short-term parking impacts road traffic more than long-term parking. It was also found one-day parking reduced road capacity minimally. Alfaro [12] suggested the usage of road space for parking due to increasing demand contributes to the traffic congestion.

Meanwhile, un-controlled parking might encourage travellers to abuse the limited space for parking, double parking, improperly parked and parking on prohibited locations affecting traffic flow as well as road safety [13]. Therefore parking should be controlled. These phenomenon are occurred not only in developed countries, but also in many developing countries such as in Malaysia [14] and Philippine [12], including in the CBD of Padang CityIndonesia. Although parking control studies have been undertaken in other places, yet it might not be applicable in elsewhere. Therefore, developing parking control for Padang City becomes essential as its fits the local conditions.

Padang is the capital city of West Sumatra. With the total population above one million individuals, it is categorized as one of newly emerge big cities in Indonesia. Figure 1 shows the Padang city maps consisted of 11 counties, where the CBD is located not far from the west coast. It is a dense business area with a mix land use including major shopping centers, automobile spare parts stores, construction material, and furniture stores and also the largest traditional market in Padang City (see Figure 2).

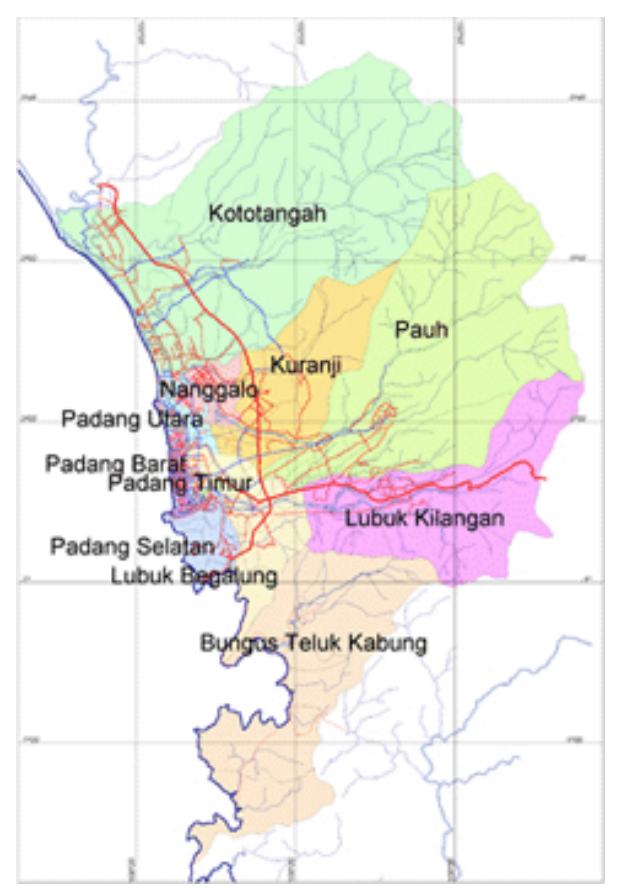

Fig. 1 Padang city map

Meanwhile, there are two major collector roads crossing the Padang CBD from East to West and from South to North. Those are (1) M. Yamin Road, and (2) Hiligoo Road - Pasar Raya Road and Permindo Road where both are one-way roads (see the sketch on Figure 3). Generally speaking, both major roads are congested, especially during working day. On-street parking lots are provided along these roads where Figures 4-7 represent the existing on-street parking conditions and behaviour.

It can be seen that some vehicles were parked in the prohibited area contributing to the decrease of the road capacity. It can also be seen cars were parked with different angles in the same side of the road resulted in inconvenience for the traveller to enter and exit the parking lots.

Meanwhile, not all of provided on-street parkings are marked with clear markings as well as clear parking signs whether on-street parking is allowed or prohibited along that road section. Yet, some vehicles were parked improperly despite the parking lot is marked clearly (see Figure 4-7 respectively for more details).

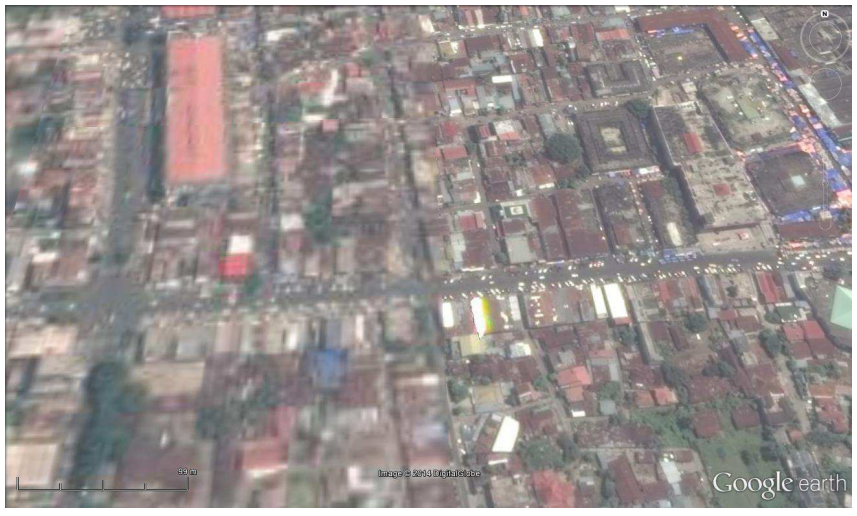

Fig. 2 A dense and mix land use of Padang CBD

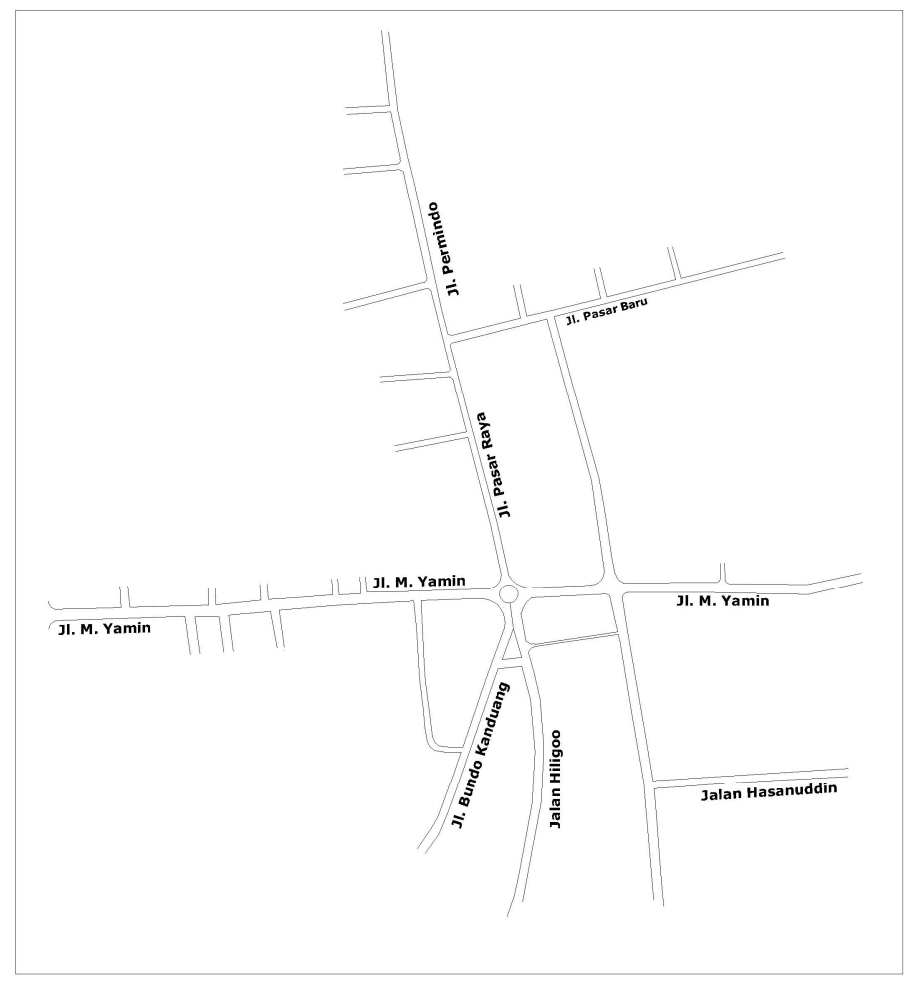

Fig. 3 Major roads in Padang CBD 


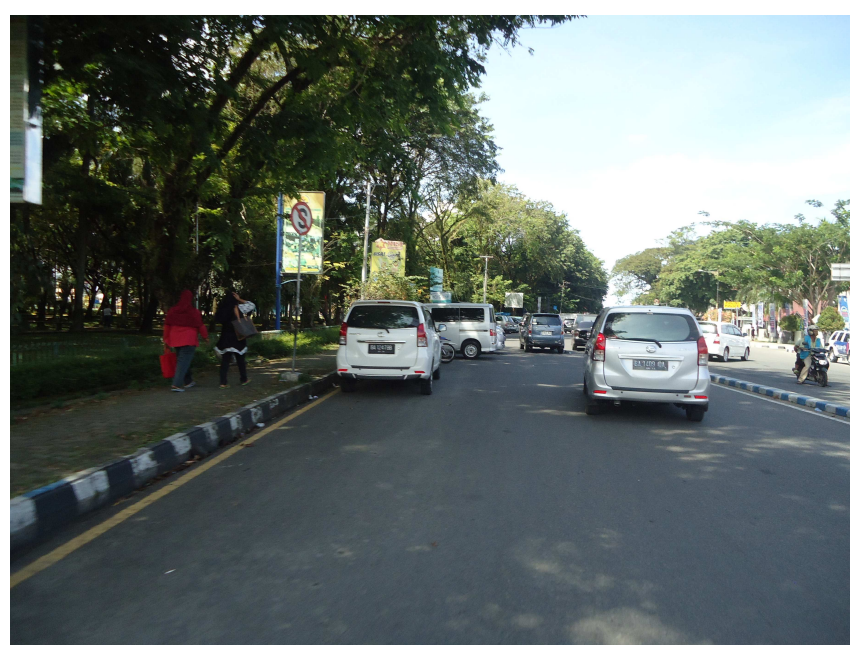

Fig. 4 Parking in a prohibited area

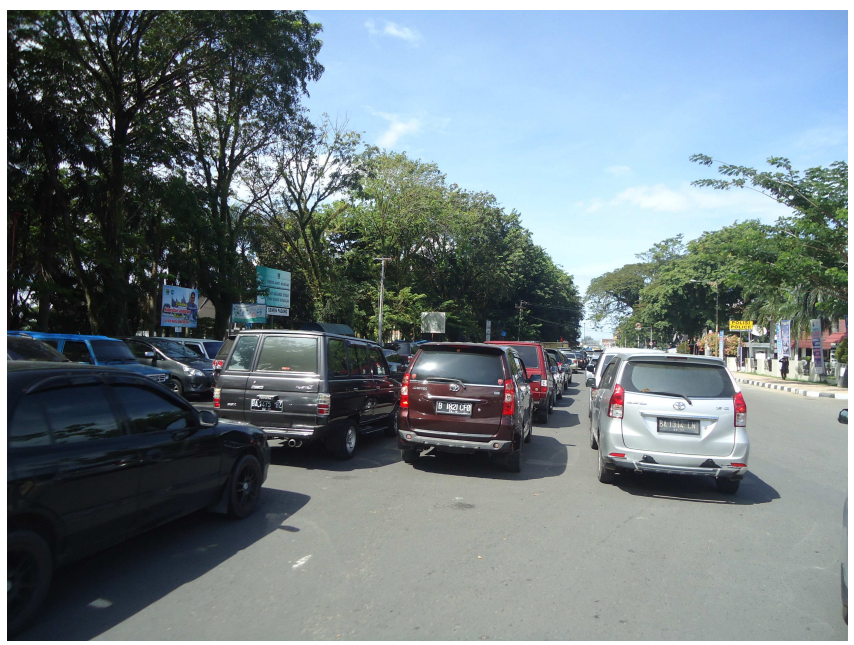

Fig. 5 Different parking angles in the same side of the road

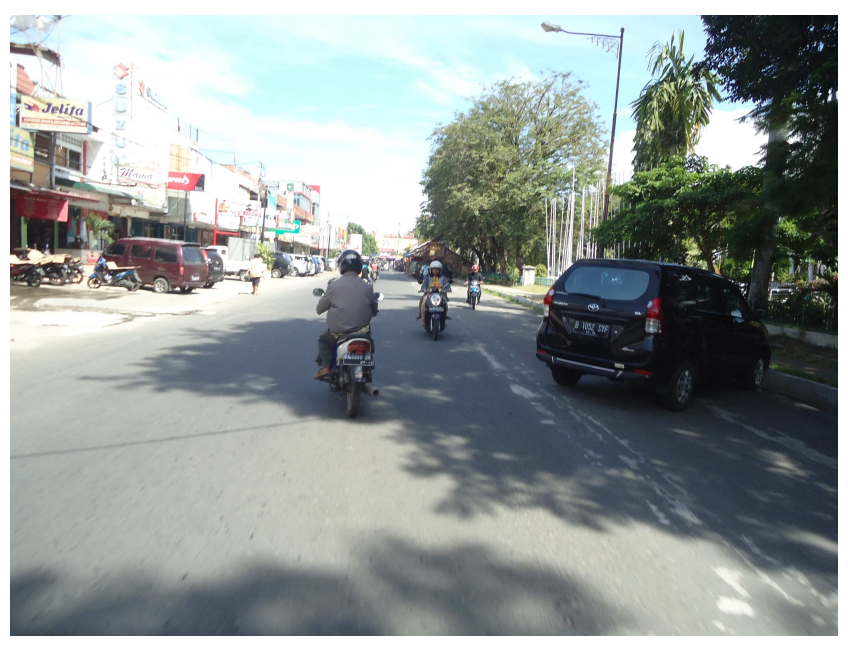

Fig. 6 On-street parking without parking mark

\section{MATERIAL AND METHOD}

The demand for on-street parking varies during the day ranging from 17 to 102 parking lots. In average, the parking demand is about 60 lots where the highest demand belongs to M. Yamin Road followed by Permindo and Hiligoo Roads. Figure 9 depicts the on-street parking demand in the Padang CBD. Figure 10 display mode shift trends in Padang City suggesting more travellers shifted from public transports to private vehicles. It resulted in more traffic loaded to the city roads, especially inside the CBD. It was described by Yaldi [15] that congestion occurs mainly inside CBD and also some areas located in outside CBD but still in the city of Padang. Further, severe congestion level causing considerable low Level of Service (LoS) was occurred in some spots and could reach as low as F.

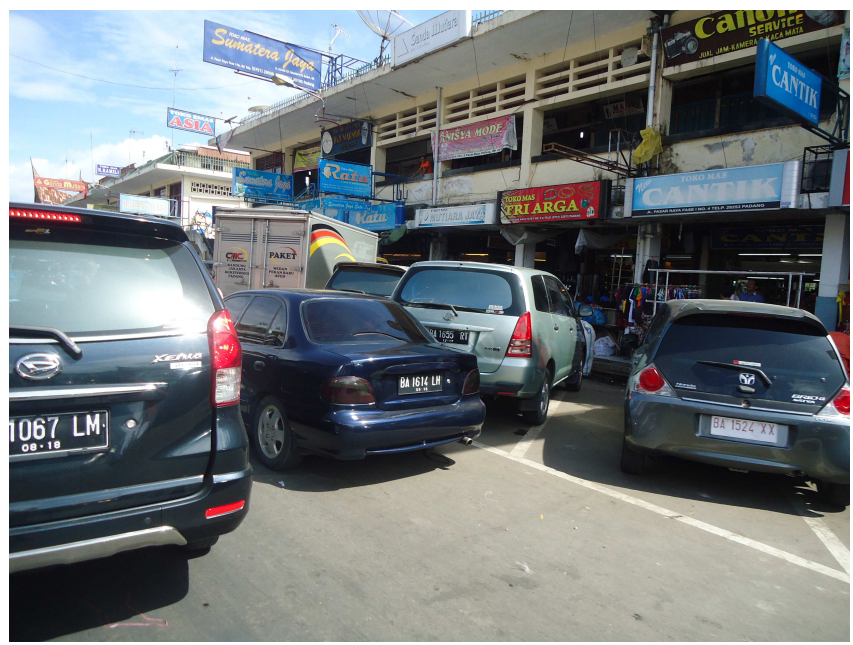

Fig. 8 Improperly parked vehicles

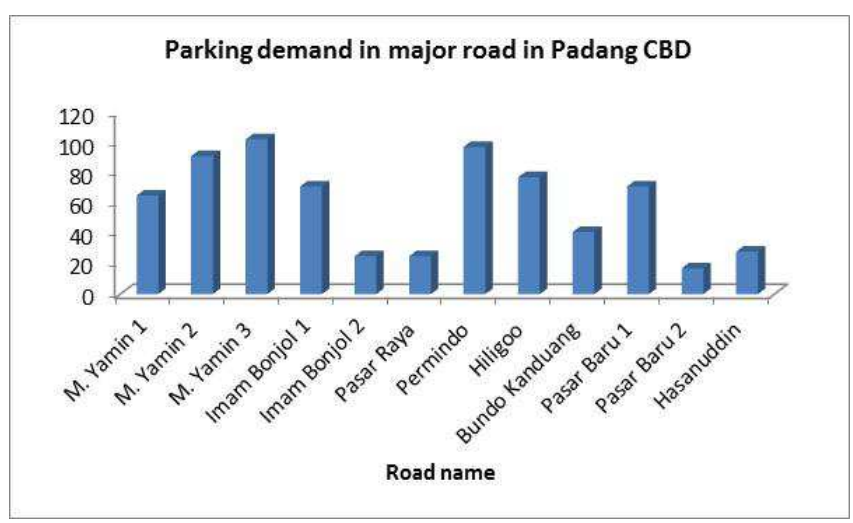

Fig. 9 Hourly on-street parking demand

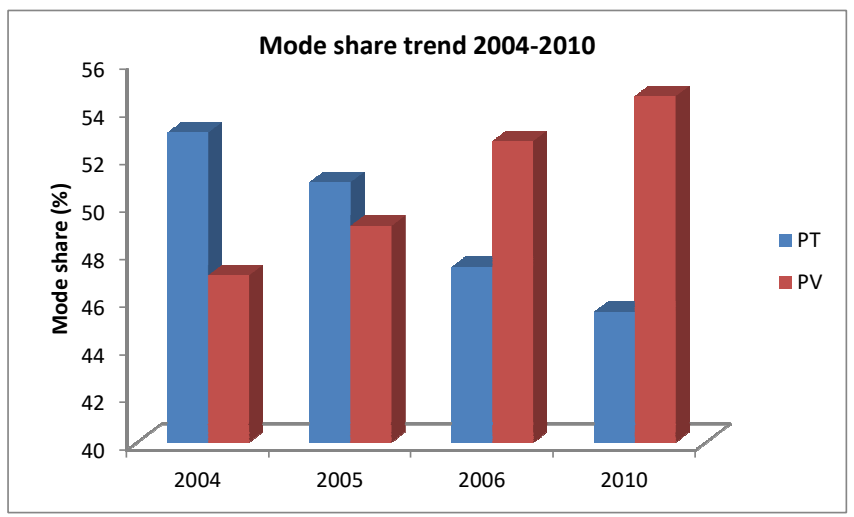

Fig. 10 Mode share and trend in Padang city

The potential loss due to congestion for Padang City would reach above Rp.900 Billion or 3\% of the 2012 GDRP. 
This number is significantly much higher than the budget allocated by the local government for transport sector. It is even higher than all sector's budget combined together. Therefore, strategic efforts must be undertaken immediately to prevent further damages to urban economic and social life by optimizing the transport supply facilities as well as strengthening the transport demand management, including parking systems.

In order to minimize the impacts of road traffic by means of parking controls, it is important to investigate the variable considered essential in optimizing the existing parking supply. It is also expected could reduce the private car usage and hence mode shift from private cars to public transports occurred. It can be achieved by understanding the existing parking behavior.

Thus, identifying the value for variables considered important for the traveller such as parking cost, parking location, parking distance to the activity center, Willingness to Pay (WTP) as well as Ability to Pay (ATP) are necessary. These data are commonly obtained by conducting a series of surveys, including Stated Preference survey [10]. Therefore, a combination of Revealed Preference (RP), Stated Preference and Parking Occupancy surveys have been undertaken in Padang CBD aimed at defining the best proposed scheme of parking control.

\section{RESULTS AND DISCUSSION}

The results can be seen in Figures 11-13 and also reported by Table 1 . It is found that the average parking duration was about 85.8 minutes or nearly 1.5 hours per vehicle. The longest parking duration was higher than three hours while it is 30 minutes or less for the shortest ones. The RP survey indicates the majority of the motorists parked within 1-2 hours. From Figure 11 it can be assumed $72 \%$ travellers parked for more than one hour and the rest is not more than an hour.

In order to optimized the parking facilities, it then could be assumed that $28 \%$ parking lots should be allocated for 60 minute parking while $36 \%$ parking lots are provided for 120 minute and >120-minute each. Yet, long-term parking lots are preferred as the impact of short-term parking to the road capacity is more obvious [11].

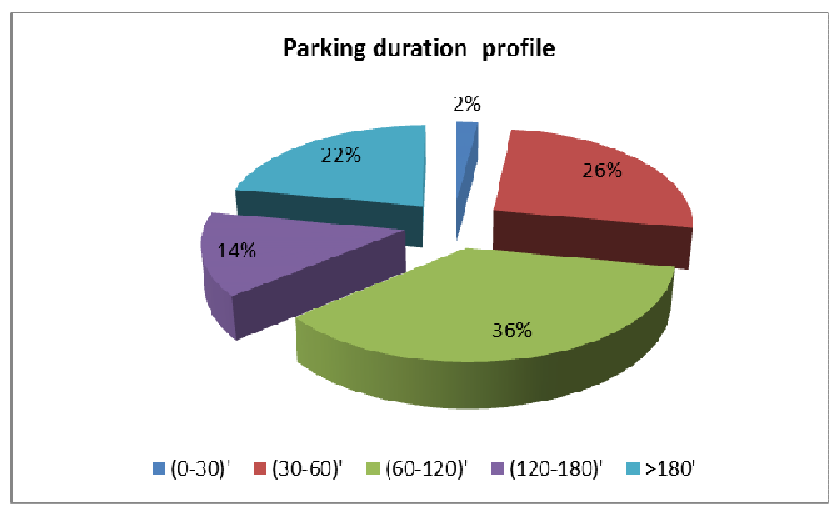

Fig. 11 Parking duration profile in Padang CBD

Further, about $96 \%$ of motorist parked in paid parking lots, including on-street and off-street parking locations suggesting mostly all of parking lots in CBD are paid parking. It is estimated about $4 \%$ respondent used unpaid parking lots as the shop owner. The average parking cost paid by the motorist to park is Rp.3000 (1USD equals to approximately Rp.15000) and the same amount was paid by the majority of the motorist as depicted by Figure 12. It was obtained from the RP survey that about 38\% respondent used off-street parking suggesting the majority of motor vehicles are parked on road side interrupting the traffic flow. In some countries like Japan, on-street parking is basically prohibited due to its impact towards road capacity [10].

TABLE I

PARKING DURATION DistRIBUTION IN PADANG CBD

\begin{tabular}{|l|l|l|}
\hline No. & Parking duration (minutes) & \% Respondent \\
\hline 1 & $<60$ & 28 \\
\hline 2 & $60-120$ & 36 \\
\hline 3 & $>120$ & 36 \\
\hline
\end{tabular}

Meanwhile, it was found the motorist desires to park in on-street and off-street parking with equal percentage. This preference is considerably different compared to the existing figure where more motorists parked along the on-street parking facilities (see Tables 2 and 3 ).

This finding suggests that currently more on-street parking facilities are available than the off-street parking. Thus, it is recommended that the transport authority to provide more off-street parking facilities as desired by the motorists-yet with specific constraints such as its location from the activity centers.

In average, the motorist parked 77.5 meters from activity centers while the desired distance is much longer namely 179 meters. Tables $4 \& 5$ and Figure 13 show there is a huge gap between the existing and desired parking distances. Thus, the transport authority could reduce on-street parking supply and provide more off-street parking facilities with the average distance from the activity center is longer than 179 meters and the parking price higher than Rp.3000.

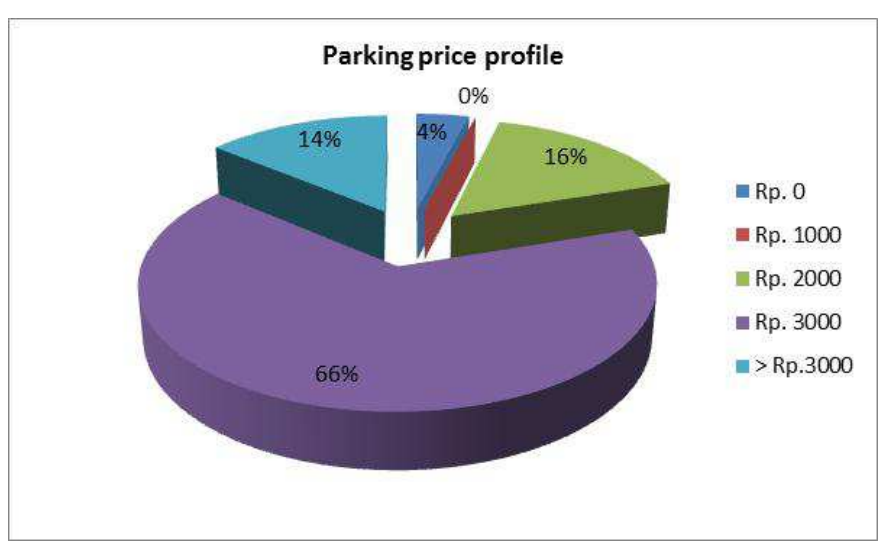

Fig. 12 Parking cost profile in Padang CBD

It is expected longer distance of off-street and on-street parking facilities towards the activity centers would cause fewer travellers using private cars and would shift to public transports reducing fuel consumption, congestion and traffic accident numbers. 
Furthermore, limited parking supply as well as expensive parking cost would encourage the motorist to park in the remote area [16]. Thus, it is expected less traffic on the CBD road and congestion could be avoided, especially during peak time. Yet, this expectation must be further investigated. Thus, an SP survey was conducted assessing the motorist behavior towards the virtual parking facilities scenarios as depicted by Figure 14.

TABLE II

EXISTING PARKING LOCATIONS

\begin{tabular}{|c|l|l|}
\hline No. & Parking location & \% Respondent \\
\hline 1 & On-street & 66 \\
\hline 2 & Off-street & 34 \\
\hline
\end{tabular}

TABLE III

THE PREFERRED PARKING LOCATIONS

\begin{tabular}{|c|l|l|}
\hline No. & Preferred parking location & \% respondent \\
\hline 1 & On-street & 50 \\
\hline 2 & Off-street & 50 \\
\hline
\end{tabular}

TABLE IV

EXISTING PARKING Distance to THE ACTIVITY Centre IN PADANG CBD

\begin{tabular}{|l|l|l|}
\hline No. & Existing parking distance (m) & \% Respondent \\
\hline 1 & $<50$ & 46 \\
\hline 2 & $50-100$ & 40 \\
\hline 3 & $100-150$ & 4 \\
\hline 4 & $150-200$ & 6 \\
\hline 5 & $200-250$ & 4 \\
\hline
\end{tabular}

TABLE V

Preferred Parking Distance to The Activity Centre In PaDANg CBD

\begin{tabular}{|l|l|l|}
\hline No. & Preferred parking distance $(\mathbf{m})$ & \% Respondent \\
\hline 1 & $<50$ & 18 \\
\hline 2 & $50-100$ & 12 \\
\hline 3 & $100-150$ & 4 \\
\hline 4 & $150-200$ & 50 \\
\hline 5 & $200-250$ & 66 \\
\hline
\end{tabular}

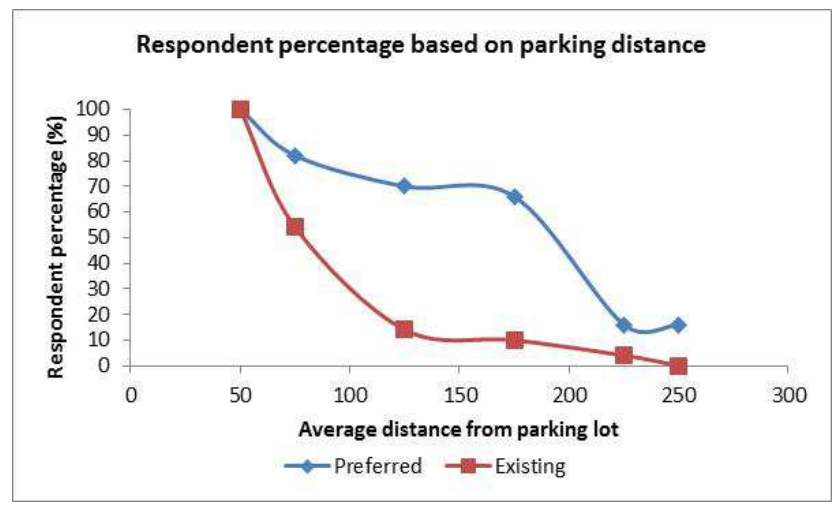

Fig. 13 Existing and preferred parking distance

In order to investigate the behavior of travellers in selecting virtual parking facilities based on particular characteristics, an SP survey has been undertaken and designated for three different schemes based on RP survey outputs as can be seen in Figure 14. The purpose is to determine the behavior of the travellers towards the proposed parking scheme including parking locations (onstreet or off-street) and parking price system (fix or progressive) with specific security and convenience devices.
The expected results are the WTP of the travellers for each parking scheme and also the ATP based on the traveller monthly income could be figured out and hence could be used to develop suitable parking control policy. The results are reported in Table 6 and Figures 15-17.

The SP survey outputs reported in Table 6 suggests the motorists have the same preference of parking schemes for short-time parking. However, more motorists seem to prefer the first parking scheme once the parking price increased to Rp.4000 - Rp.5000 as reported by Table 6 .

Meanwhile, more motorists choose Parking Scheme 3 once based parking price reaches Rp.6000. Thus, parking price Rp.4000 - Rp.5000 is considered as the boundary where motorist preference moves from on-street parking to off-street parking.

Yet, the motorists prefer the first parking scheme rather than others although more motorists have WTP Rp.6000 for parking scheme 3. It suggests a better parking facilities is worthwhile a higher parking cost. These findings demonstrate the motorist decisions are affected by the parking prices, parking time limits and parking locations as well as parking facilities.

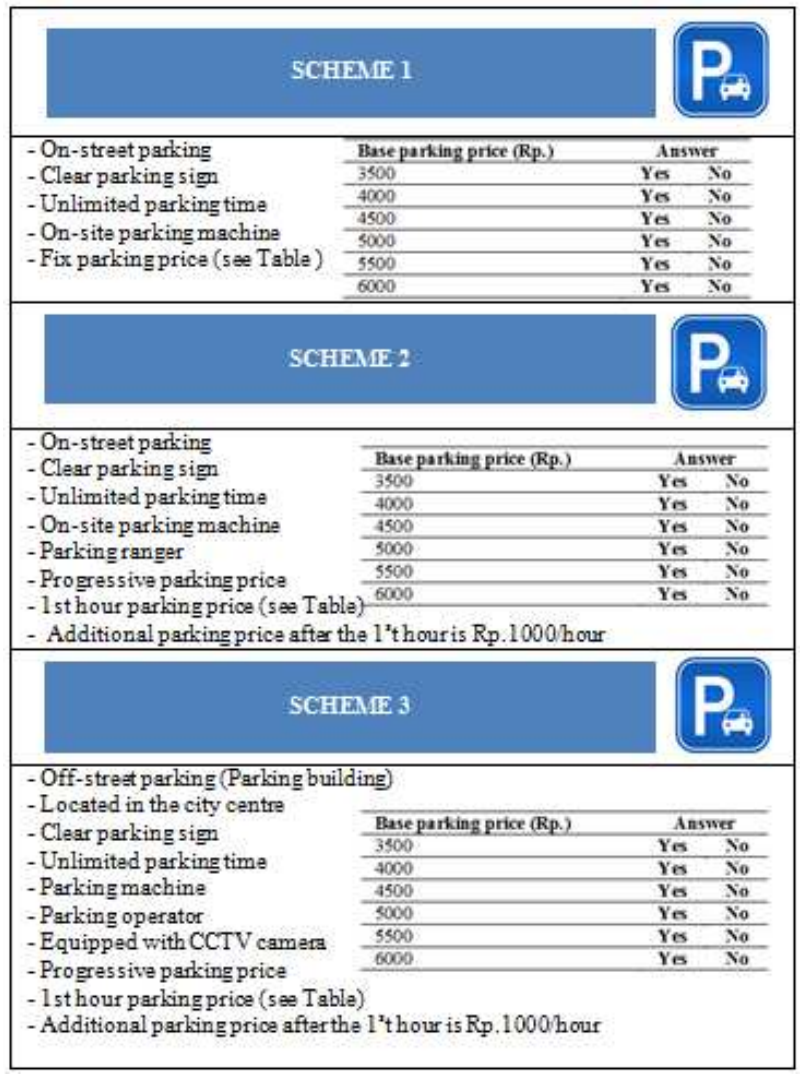

Fig. 5 Proposed virtual parking schemes

It also can be seen in Table 6 and Figure 15 where in average more than a half of respondents are willing to pay the parking prices for all of proposed parking schemes not more than Rp.4000 - Rp.5000. In general, the motorists would use parking facilities charged up to Rp.5000 with a percentage of $92 \%, 82 \%$, and $74 \%$ for parking schemes 1,2 , and 3 respectively. Thus, it can be assumed that the motorists prefer on-street parking with fix prices more than other schemes. In the meantime, the ability to pay for 
parking is reported reaching Rp.6000 although some motorists are able to pay up to Rp.15000. Once the WTP and ATP are superimposed, the motorists WTP and ATP for parking facility is estimated above Rp.4000 but not more than Rp.5000 as represented by more than $70 \%$ of the motorists. The summary of the findings from this study is then is reported in Table 7. The transport authority is recommended to develop its local parking control policy based on these findings depending on which scheme is to be applied. Thus, the government could provide more off-street parking facilities, yet with a based parking price above Rp.6000 and paid progressively. Meanwhile, the on-street parking facilities should be minimized where more longterm parking lots are recommended with a based parking price above Rp.4000 and paid progressively.

TABLE VI

RESPONDENT PERCENTAGE FOR DIFFERENT PROPOSED PARKING SCENARIOS

\begin{tabular}{|c|c|c|c|c|c|c|}
\hline & \multicolumn{5}{|c|}{ \% respondent } & \multirow{2}{*}{$\begin{array}{l}\text { Total } \\
(\%)\end{array}$} \\
\hline & $<30^{\prime}$ & $\begin{array}{l}(30- \\
60)\end{array}$ & $\begin{array}{l}(60- \\
120)\end{array}$ & $\begin{array}{l}\text { (120- } \\
180)^{\prime}\end{array}$ & $>180$ & \\
\hline Scenario 1 & & & & & & \\
\hline Parking price 1 & 0 & 10 & 10 & 2 & 2 & 24 \\
\hline Parking price 2 & 2 & 12 & 24 & 10 & 18 & 66 \\
\hline Parking price 3 & 0 & 4 & 2 & 2 & 2 & 10 \\
\hline Scenario 1 & & & & & & \\
\hline Parking price 1 & 0 & 8 & 12 & 4 & 6 & 30 \\
\hline Parking price 2 & 2 & 12 & 18 & 8 & 12 & 52 \\
\hline Parking price 3 & 0 & 6 & 6 & 2 & 4 & 18 \\
\hline Scenario 1 & & & & & & \\
\hline Parking price 1 & 0 & 6 & 8 & 2 & 4 & 20 \\
\hline Parking price 2 & 2 & 10 & 22 & 8 & 12 & 54 \\
\hline Parking price 3 & 0 & 10 & 6 & 4 & 6 & 26 \\
\hline
\end{tabular}

Parking price $1=$ Rp.3000-Rp.3500, Parking price $2=$ Rp.4000-5000, Parking price $3=\mathrm{Rp} .6000$

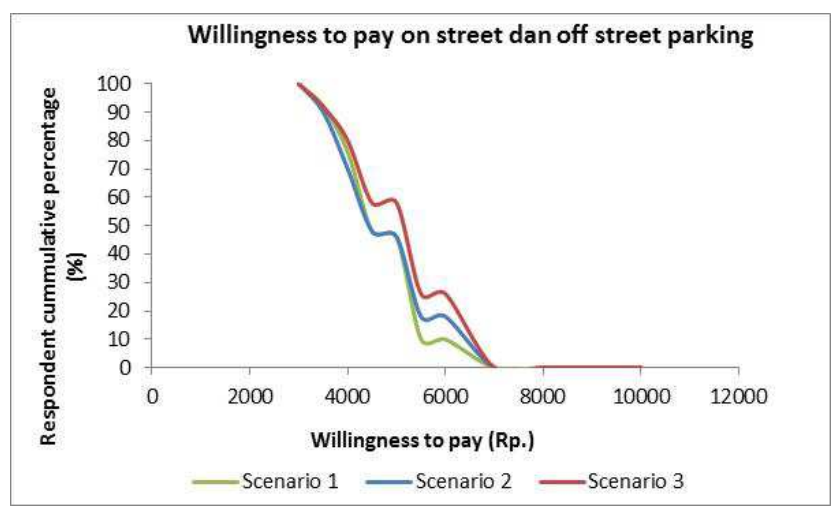

Fig. 15 WTP for different parking schemes

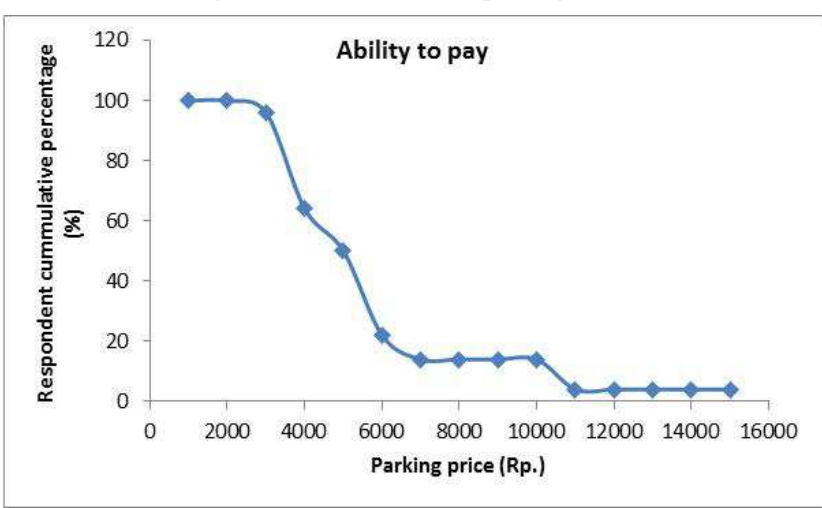

Fig. 16 Motorist ATP for parking

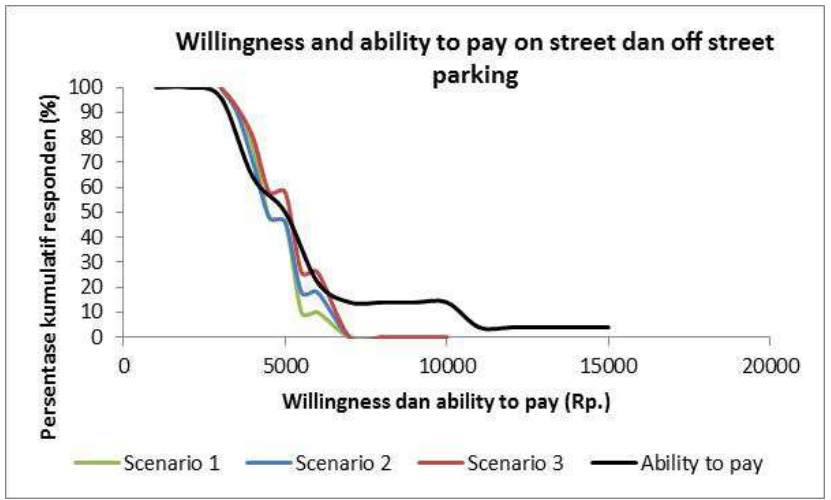

Fig. 17 WTP and ATP for different parking schemes

TABLE 7

THE PROPOSED PARKING CHARACTERISTICS FOR PARKING CONTROL AND MANAGEMENT SCHEMES

\begin{tabular}{|l|l|l|}
\hline Parking location & $\begin{array}{l}\text { On-street } \\
\text { parking }\end{array}$ & $\begin{array}{l}\text { Off-street } \\
\text { parking }\end{array}$ \\
\hline Price scheme & $\begin{array}{l}\text { Progressive } \\
\text { pricing }\end{array}$ & $\begin{array}{l}\text { Progressive } \\
\text { pricing }\end{array}$ \\
\hline Based parking price (Rp./hour) & 4000 & 6000 \\
\hline Parking distance-activity centre (m) & $>179$ & $>179$ \\
\hline Provided parking lots (\%)* & & \\
\hline - Maximum 60 minute & 27 & 38 \\
\hline - 60-120 minutes & 35 & 24 \\
\hline - >120 minutes & 38 & 38 \\
\hline Future parking development locations & & $\sqrt{ }$ \\
\hline
\end{tabular}

* More one-day parking lots are recommended

\section{CONCLUSIONS}

The main finding from this study suggests the transport authority could control road traffic so that its negative impacts could be reduced by controlling the existing parking facilities. The existing parking supply provides on-street parking more than the off-street parking. This situation could lead to severe traffic congestion during peak hour due to road space usage for parking. It is recommended the supplied on-street parking lots to be re-assessed and optimized by applying progressive pricing and limited parking duration based on Table 6 .

The average on-street parking should be located not less than 179 meters from the activity centre where $73 \%$ parking lots are provided for parking duration longer than one hourpreferred for one-day parking and more expensive price. Meanwhile, the transport authority could also manage the parking supply by providing more off-street parking facilities with progressive pricing. The based parking price should be not less than Rp.6000 with an average distance from the activity centre $>179$ meters where only $38 \%$ parking lots are for parking duration less than one hour.

Although applying the parking control policy based on the findings from this study is probably considered as difficult, unpopular and politically sensitive, the government are encouraged to persuade the public and implement the policy gradually and also by engaging the community for the sake of future economic and generation. 


\section{REFERENCES}

[1] BPPN, "Effort to minimize the petrol consumption in transportation sector (in Bahasa)," ed. Jakarta: Bappenas (National Planning Body) of Indonesian Republic, 2006

[2] Bappenas, "Analysis of petrol consumption pattern (in Bahasa)," vol. , ed. Jakarta: Bappenas (National Planning and Development Agency) of Indonesian Republic, 2011.

[3] S. Morichi, "Long-term Strategy for Transport System in Asian Megacities," Journal of the Eastern Asia Society for Transportation Studies, vol. 6, pp. 1-22, 2005.

[4] S. Soehodho, "Motorization in Indonesia and Its Impact to Traffic Accidents," IATSS Research, vol. 31, pp. 27-33, 2007.

[5] G. Yaldi, et al., "Local Traffic and Public Transport Portraits: A case study in padang City " presented at the The 17th FSTPT International Symposium, Jember, Indonesia, 2014.

[6] K. Gwilliam, "Cities on the Move: A World Bank Urban Transport Strategy Review," World Bank, Washington, DC2002.

[7] H. Ma, et al., "Motorization Process and Management in Big Cities in China," IATSS Research, vol. 31, pp. 42-47, 2007.

[8] W. Yan-ling, et al., "Current Situation and Analysis of Parking Problem in Beijing," Procedia Engineering pp. 777 - 785, 29 September - 1 October 20042016.
[9] P. Luathep, et al., "Challenge of Public Transport Planning in Private Vehicle Dominated Community," Journal of the Eastern Asia Society for Transportation Studies, vol. 11, pp. 1122-1139, 2015.

[10] Y. Tsuboi, et al., "Analysis of Parking Lot Choice Behaviors by Utilizing Accounting Data," Journal of the Eastern Asia Society for Transportation Studies, vol. 11, pp. 523-536, 2015.

[11] S. Wijayaratna, "Impacts of On-street Parking on Road Capacity," in Australasian Transport Research Forum, Sydney, 2015.

[12] D. J. G. Alfaro, et al., "On-street Parking Evaluation Divisoria, Cagayan De Oro City," Journal of the Eastern Asia Society for Transportation Studies, vol. 11, pp. 1710-1725, 2015.

[13] W. L. Yue, "Parking management in Saudi Arabia: Is there any solution?," in 27th Australasian Transport Research Forum, Adelaide, 2004.

[14] S. A. A. Syed Adnan and A. A. Kadar Hamsa, "Factors Influencing the Parking Demand of the Park and Ride Facility at Putrajaya Public Transportation Terminal," Journal of the Eastern Asia Society for Transportation Studies, vol. 11, pp. 1291-1306, 2015.

[15] G. Yaldi, "Some portraits and problems of Indonesian transportation systems," presented at the 15th FSTPT International Symposium, Bekasi, Indonesia, 2012.

[16] Y. Bu and T. Pershouse, "A practical application of modelling remote parking behaviour," in Australasian Transport Research Forum, Sydney, 2015. 